\title{
STEPHEN HARPER: AUTHORITARIAN PARTISAN AND RADICAL SOCIAL CONSERVATIVE IDEOLOGUE?
}

\author{
STEVE PATTEN
}

University of Alberta

\begin{abstract}
Martin, Lawrence. 2010. Harperland: The Politics of Control. Toronto: Viking Canada. ISBN 978-0-670-06517-2. Hardcover: 35.00 CAD. Pages: 301.

Nadeau, Christian. 2011. Rogue in Power: Why Stephen Harper is Remaking Canada by Stealth. Toronto: Lorimer. ISBN 978-1-55277-730-5. Paperback: 22.95 CAD. Pages: 159.
\end{abstract}

A lot has been written about Stephen Harper over the years. He first caught the attention of followers of Canadian politics when he was Chief Policy Officer for the fledgling Reform Party of Canada. He subsequently served as a Reform MP from 1993 to 1997, before stepping aside from partisan politics to head the uncompromisingly right wing National Citizens Coalition. When Harper returned to politics in 2002 it was to lead the Canadian Alliance. But, a little over a year later he was at the helm of the newly unified Conservative Party of Canada. The Harper Conservatives unseated Canada's Liberal government in 2006, and for the next five years Stephen Harper was the successful head of a minority Conservative government. Then, in May 2011, Harper and the Conservatives won a majority of seats in the House of Commons, and today Stephen Harper governs with the absolute sense of political security that our parliamentary system affords majority governments. It is now more important than ever that Canadians understand Harper, his motivations, goals and approach to governance.

The popular press and most of the books about Stephen Harper portray him as a reasonably pragmatic right-of-centre politician whose values speak to a significant and growing minority of Canadians. ${ }^{1}$ To be sure, Harper's desire to control political messaging has been criticized, he was condemned for using prorogation to skirt the will of Parliament, and his refusal to accept and respond to expert opinion on law and order issues is regularly put in a negative light. But, until recently, the most widely read books

\footnotetext{
${ }^{1}$ Of course, there are important exceptions. For example: Healey 2008; McDonald 2010. 
on Harper tempered their criticism; in those volumes his politics were seldom characterized as ideologically extreme or overly undemocratic.

Two recent books paint harsher portraits of Stephen Harper. Lawrence Martin's Harperland and Christian Nadeau's Rogue in Power suggest Harper is a radical right wing social conservative, an aggressive partisan, deeply authoritarian, secretive, and aiming to bring fundamental social and political change to Canada. This essay takes a look at these books, their analysis of Harper's social conservatism, his partisan and authoritarian character, and his efforts to entrench a new politics of Conservative dominance.

\section{Harperland}

Lawrence Martin is a respected Ottawa-based public affairs columnist, currently covering Canadian national politics for the Globe and Mail. His latest book, Harperland: The Politics of Control, chronicles the first few years of Stephen Harper's tenure as Prime Minister. Drawing on his own observations, a wide range of press reports, a number of revealing interviews with Conservative insiders, and a small amount of secondary research, Martin chronicles events in a manner that is insightful, yet accessible to a popular, non-academic audience. The book's analysis of Stephen Harper's ideological motives and political style provides revealing insights into how Harper-then Prime Minister of a minority Conservative government-exercised executive power in an effort to dominate Ottawa and set in motion a transformation of the institutions and culture of Canadian politics.

As a chronicling of events, Harperland is an enjoyable example of what political journalism can offer when not confined by the space and deadlines of the daily press. Martin reviews key events that propelled Stephen Harper into the Prime Minister's office, and then examines many of the defining political moments and public policy initiatives that, upon reflection, serve to illuminate important aspects of Harper's ideological orientation, partisan attitude and leadership style. The book touches on a range of policy issues, including the Harper Conservative's early accountability promises, their abandonment of the Kyoto Protocol, their uncompromising support of Israel, their law and order agenda, and their opposition to Vancouver's Insite supervised injection site. It also analyses Harper's political management of the ill-fated Liberal-NDP coalition project, the Afghan detainee transfer controversy, and the public outcry regarding the prorogation of parliament. But, from the start, Martin's real goal is to paint a picture of Stephen Harper's personality as partisan and a leader.

The picture of Harper that emerges in Harperland is not a flattering one. Martin depicts the Prime Minister as a deeply ideological and aggressively partisan man who is representative of the hard right of the Conservative Party. Throughout the book, Harper is characterized as motivated by a "hatred" of the Liberals and a pervasive animosity 
toward the existing political order of liberal Canada. He is portrayed as driven to break the Liberal Party brand and dominate Canadian politics by concentrating power, controlling information, limiting the independence of policy-making, regulatory and watchdog bodies, and manipulating wedge politics to the Conservative's advantage. There is little in this depiction of Stephen Harper to suggest that the Conservative Prime Minister will be satisfied if Canada remains unchanged after his tenure at the pinnacle of political power.

\section{Rogue in Power}

Christian Nadeau is a professor of Philosophy at l'Université de Montréal, but also something of a public intellectual. Having published a number of political commentaries on the Idées page of Le Devoir, Nadeau gained a reputation as a critic of the Harper government, particularly with regard to international security policy, the Omar Khadr case, Canada's role in Afghanistan, and the government's policies regarding Israel and the occupied Palestinian territories. In the opening lines of Rogue in Power: Why Stephen Harper is Remaking Canada by Stealth, Nadeau states that he is "ashamed of our current government" and "appalled by the actions it has undertaken" (9). There is no pretence of either academic or journalistic objectivity. Instead, Nadeau's stated purpose is to reveal the ideological motivations that lay behind Harper's policies, and then to provide readers with a framework for engaging in a critical evaluation of those motivations and policies.

The ideological portrait of Stephen Harper that Nadeau paints emphasizes the Conservative Prime Minister's commitment to the traditional values of social conservatism. Nadeau argues that Harper believes the struggle to advance economic conservatism and individual freedom has been largely won, thus his goal is now to orchestrate a fundamental shift in social values. Harper, he contends, is a Burkean traditionalist, committed to traditional social values and willing to use moral and legal sanctions to enforce those values. In Rogue in Power Nadeau warns Canadians that Stephen Harper wants to "crush once and for all what remains of the left's agenda: its vision of a just society" (31). He argues that the Harper Conservative's policies aim to change the political and social organization of the country through a "well-planned and organized attack on justice and democracy as we have understood them to date" (21).

Nadeau's volume is intended as a political intervention-and activist essay-that aims to arm non-academic readers with the philosophical tools and points of reference that are necessary for a critical analysis of the policy agenda of Stephen Harper's Conservative government. This is accomplished with a wide-ranging discussion of domestic, international, social and economic policies. But, each chapter begins and ends with a more philosophical discussion of the contrast between the sort of just society liberalism that Nadeau considers to be Canada's dominant public philosophy, and 
Harper's moralistic social conservatism. At the core of Nadeau's lesson in applied political philosophy is the contention that Harper's conservatism relies on a "concept of good" that is rooted in a social traditionalism that is not widely accepted by Canadians. Nadeau encourages his readers to consider the contrast between Harper's philosophy and Canada's traditional commitment to a "concept of justice," which is based on widely accepted principles such as fairness. It is clear that Nadeau believes critically thinking democrats will reject the impositional nature of Harper's social conservatism and join those who oppose the Conservative government.

\section{Harper's Social Conservatism}

While progressive scholars and left-leaning activists have consistently identified Stephen Harper as a right wing ideologue whose values have more in common with American neo-conservatism than mainstream Canada, the mainstream political press and most of the bestselling books that chronicle Harper's rise to power are, with few exceptions, much less definitive about Harper's status as a right wing ideologue. In his book on Stephen Harper and the success of his political machine, Harper's former advisor, Tom Flanagan, characterizes Harper as a pragmatist who works to position himself in the "middle," not the hard right, of Canada's conservative coalition (Flanagan $2007,19)$. In recent years some conservative-minded commentators have gone further and attacked Harper for diluting conservative principles and moving the party to the left by racking up deficits, expanding government and refusing to recriminalize abortion or repeal gay rights (Nichols 2007; Wente 2011).

Martin and Nadeau do their readers a service by rejecting these efforts to paint Harper as centrist conservative. Martin characterizes Harper as being on the "hard right" of Canada's conservative tradition, and certainly to the right of other postwar Conservative leaders (23). Nadeau labels Harper a "revolutionary" because he has broken with Canada's Tory tradition and embraced an American-style neo-conservatism that presents a fundamental challenge to the progressive values consensus that has dominated Canadian politics for four decades (12-3).

It is worth recalling that Stephen Harper first became active in partisan politics in the early 1980s because he believed Brian Mulroney's election presented an opportunity to usher in the sort of "fundamental conservative transformation" that was going on in the UK and America under Margaret Thatcher and Ronald Reagan (Plamondon 2006, 8790). When Brian Mulroney failed to act as decisively as Harper would have liked, he joined Preston Manning to help found the Reform Party of Canada. Then, fifteen years later, when Harper ran for the leadership of the Canadian Alliance, he rejected proposals to cooperate with the red tory Joe Clark because he wanted the Alliance "to be a clear voice for conservatism" (Plamondon 2006, 222). But what kind of conservatism does Harper espouse? 
Like others, Martin and Nadeau regard Harper as a libertarian and an economic conservative with a complicated relationship to social conservatism. But, somewhat uniquely, they refuse to downplay his social conservatism. Nadeau, in particular, returns time and again to the task of demonstrating the political significance of Harper's social conservatism, and Martin suggests that in recent years the Harper Conservatives have often been truer to social conservatism than economic conservatism (244-45). This assessment is at odds with the assessment of mainstream Harper watchers who have regularly avoided identifying him as a strong advocate of social conservatism. Looking back to his years shaping the early Reform Party, Stephen Harper's biographer, William Johnson, argues that the ideas Harper brought to the table were rooted in strong free market principles and a commitment to smaller government, but "not the slightest hint of social or moral conservatism" (Johnson 2005, 68). Similarly, in 2005, Lloyd Mackey argued that Harper actively encourages moral traditionalists to lower their policy expectations, and "let things happen incrementally when the times are right" (Mackey 2005, 62). Finally, in his book on Harper's rise to power, the popular Maclean's columnist, Paul Wells, argues that social conservatives do not view Harper as "one of them" because he is adverse to "legislating right moral conduct" (Wells 2006, 314).

As a primary piece of evidence of Harper's commitment to social conservatism, Martin and Nadeau both cite a speech Harper made to Civitas, a right wing thinkers group, in 2003 (Nadeau, 31-33; Martin, 245). Although this speech was given before Harper became Prime Minister, and it is not an official government or party policy document, it provides very revealing insights into Harper's thoughts on the state of ideological struggle in Canada. In that speech Harper argues that the postwar welfare state damaged Canadian families and had a negative impact on social values. He then suggests the modern left has slid from the sort of socialistic moralism that underpinned the welfare state, to an even more troubling moral relativism and nihilism that represents "a rebellion against all forms of social norms and moral tradition in every aspect of life." In response, Harper encourages conservatives to rethink their political priorities. He argues that because free market rationalities already dominate economic policy debates, "the real agenda and the defining issues have shifted from economic to social values." This means "not just worrying about what the state costs, but also worrying about what the state values" (Harper 2003).

Those who downplay Harper's social conservatism typically claim that despite the fact that Harper's approach to the Christian gospel and his chosen place of worship mark him as a member of Canada's evangelical community, he has nurtured his economist persona and not allowed his faith to dominate his politics (Mackey 2005). Given this, they conclude that to the extent that the Conservative government espouses social conservatism, this aspect of the party should be understood as evidence of the influence of prominent voices of the Christian right within Harper's cabinet and the Prime Minister's Office (PMO). Martin and Nadeau accept the existence of such forces, but 
draw our attention to Harper's own social conservatism and commitment to act on moral issues. It is this analysis that they rely on to explain, among other things, the Conservative government's affirmative action review, the defunding of Toronto's Gay Pride festival, cracking down on gambling and illicit sex, the law and order agenda, raising the age of sexual consent, and wanting to exclude abortion and contraception for the international maternal health initiative (Martin, 245-6; Nadeau, 78).

It is certainly true, as Martin argues, that Harper often finds it politically necessary to "walk a fine line" between pleasing social conservatives-particularly the pro-lifers-in his caucus, and being pragmatic in a society that does not share these more extreme conservative views (246). But those of us who have downplayed Harper's social conservative side-and I include myself here (Patten 2005) - should be rethinking our analysis after reflecting on Nadeau's proposition that Harper is regularly willing to allow his socially conservative commitment to using the state to uphold moral standards to "override" his more libertarian and laissez-faire side (23).

\section{Harper the Authoritarian Partisan}

By focusing so much of Harperland's analysis on the "the politics of control," Lawrence Martin has drawn public attention to an important, but unflattering dimension of Stephen Harper's character. Harper is shown to be an excessive partisan with a need to dominate and an almost manic desire for secrecy and information control. In his early days in the PC and Reform parties, Stephen Harper was known more as a man of ideas-a policy wonk-rather than a partisan warrior. Of course, he was deeply troubled by the postwar liberal political consensus that was constructed under the Liberal governments of Pierre Trudeau and his predecessors, but he seemed more concerned with advancing policy ideas than he did with partisan attacks. Over time, however, Harper's partisanship has deepened to the point that Martin now describes him as driven by a "deep animosity" toward his political opponents (124). In fact, since assuming the leadership of the Conservative Party, Harper has dedicated a great deal of his strategic energies toward developing of long-term strategy to break the Liberal Party brand and create space for the Conservative Party of Canada to reign as Canada's natural governing party (6).

Harper's evolution into an authoritarian partisan has had consequences for his party and his government. Under Harper, the Conservative Party has become what Martin-following Tom Flanagan-calls a "garrison party" (193-4). That is a party that, like a military machine, is very hierarchical and demands the absolute loyalty of its troops. It is a party machine committed to a permanent campaign in which party operatives are constantly ready to defend their gains and willing to go on the attack with, for example, pre-writ ads that are designed to assassinate the opposition leader's character rather than champion policy proposals or engage voters. 
As a governing party (and as a government) the garrison party accepts the concentration of power and is ready to put "politics over policy" when there is partisan advantage at stake (25). Stephen Harper has overseen a dramatic concentration of power within the PMO and the Privy Council Office. This has been particularly true with regard to controlling communications and messaging. Under Harper there is formal system for vetting public pronouncements and controlling the media's access to both cabinet ministers and senior members of the bureaucracy (58). In ways that surpass any of his modern predecessors, Harper has concentrated power in his offices. According to Nadeau, Harper has "an extreme conception of the prerogatives of power" (36). He considers transparency and checks and balances as obstacles to governance rather than important principles of democracy. In fact, he has worked to control or hamstring many of the alternative centres of power that exist in Ottawa, including the Senate, tribunals, watchdog bodies, and committees of the House of Commons (Martin, 67). Readers should be troubled by Martin's exploration of the politics of control; it raises serious concerns regarding the quality of our parliamentary democracy and the future of our party system.

\section{Entrenching the New Politics of Conservative Dominance}

Nadeau and Martin both contend that Stephen Harper's overarching goal is to facilitate a social and political transition to a new, more conservative Canada. This requires efforts aimed at undoing Canada's postwar liberal social order, broadening public support for conservative public policies, and establishing the Conservative Party as the country's natural governing party. To move in this direction, Harper and his team are working to redefine the Conservative Party's social base of support and, very interestingly, to give birth to a new "conservative patriotism" that connects Canadianness to Conservative rather than Liberal values, policies and achievements.

The effort to transform the Conservative Party's social base of support has been in full swing for a number of years. It has involved very targeted attempts to appeal to carefully identified "market segments" - many of these coming from traditionally Liberal ethnic communities - that are family oriented, committed to traditional values, and open to accepting the proposition that taxes and government programs are a threat to the economic opportunities of hard working citizens (Martin, 94). These appeals to new Conservative supporters have required extensive outreach efforts on the part of the Conservative Party's campaign team, but government resources have also been mobilized. While identifying policies that appeal to specific targeted communities, Harper's Citizenship and Immigration Minister, Jason Kenney, has traveled extensively, always managing to combine his ministerial duties with a healthy dose of partisan outreach and relationship building that would pay off at election time (Martin, 227). The success of this strategy was evident in the May 2011 general election. 
Nadeau contends that Harper's efforts to reshape Canadian political culture and institutionalize conservatism have included a focus on putting in place policy initiatives and institutional changes that would be difficult for a subsequent government to undo. The goal has been to "make government an organ of conservatism regardless of who is in power" (16). One particularly interesting aspect of this has been the development of what Martin claims Conservative insiders call the government's new "patriot strategy" (52). Using slogans like "Stand Up for Canada," and focusing on strong national symbols like the military, the monarchy, the North, family values and Canada's traditional international allies, the Conservatives are working to construct a new sense of what it means to be Canadian (110). This is implemented through a range of symbolic and substantive changes, including through the development of a new citizenship guide that shifts to these new themes and pays scant attention to Liberal mainstays such as the environment, peacekeeping and healthcare (228). Individually, such initiatives seem almost inconsequential, but it is clear they are all a part of an effort to entrench the new politics of Conservative dominance.

\section{Conclusion}

It is often too easy for political commentators to accept what is in front of usincluding the political style and ideology of the governing party-as normal and acceptable. When following the news of the day political change often appears pragmatic and incremental. Lawrence Martin and Christian Nadeau remind us to be cautious, to take a closer look at Stephen Harper and reflect on evidence of threats to our parliamentary democracy or policy changes that represent fundamental breaks from Canadian traditions. In this, they do their readers a service.

\section{References}

Flanagan, Tom. 2007. Harper's Team: Behind the Scenes in the Conservative Rise to Power. Montreal \& Kingston: McGill-Queen's University Press.

Harper, Stephen. 2003. "Rediscovering the right agenda: The Alliance must commit to ideals and ideas, not vague decision-making processes." Citizens Centre Report. Edmonton. Vol. 30, Iss. 10., p. 73.

Healey, Teresa, ed. 2008. The Harper Record. Ottawa: Canadian Centre for Policy Alternatives. 
Johnson, William. 2005. Stephen Harper and the Future of Canada. Toronto: McClelland \& Stewart Ltd.

Mackey, Lloyd. 2005. The Pilgrimage of Stephen Harper. Toronto: ECW Press.

McDonald, Marci. 2010. The Armageddon Factor: The Rise of Christian Nationalism in Canada. Toronto: Random House Canada.

Nicholls, Gerry. 2007. “Selling out true conservatism.” National Post (April 27), A17.

Patten, Steve. 2008. “Understanding Stephen Harper." In Teresa Healey, ed. The Harper Record. Ottawa: Canadian Centre for Policy Alternatives.

Plamondon, Bob. 2006. Full Circle: Death and Resurrection in Canadian Conservative Politics. Toronto: Key Porter Books.

Wells, Paul. 2006. Right Side Up: The Fall of Paul Martin and the Rise of Stephen Harper's New Conservatism. Toronto: McClelland \& Steward Ltd.

Wente, Margaret. 2011. "Actually, he's moved the party to the left-it's known as 'finding the sweet spot'." Globe and Mail (January 25), A15. 